\title{
Bridging Pedagogical Gaps with Learner Agency
}

\section{Kathryn M. Tanaka \\ Otemae University}

\section{Robert Sheridan \\ Kindai University}

\section{Daniel Tang \\ Otemae University}

\section{Jeanette M. Kobayashi}

Konan University

\section{Reference Data:}

Tanaka, K. M., Sheridan, R., Tang, D., \& Kobayashi, J. M. (2020). Bridging pedagogical gaps with learner agency. In P. Clements, A. Krause, \& R. Gentry (Eds.), Teacher efficacy, learner agency. Tokyo: JALT. https://doi.org/10.37546/JALTPCP2019-15

Currently, many educators in Japan seek student-centered approaches to language learning. Yet, the ways these pedagogies are understood and implemented remain uneven, and there is little research to support effective methods. Here, the researchers examine Japanese EFL university students' attitudes towards student-centered learning. We elucidate how student perceptions of their language gains change when teachers, students themselves, or their peers are responsible for the preparation and teaching of lessons and material. Researchers had students from four classes teach lessons individually, in pairs, or in groups. Students designed and taught lessons based on articles from the teacher. The four groups completed surveys with quantitative aspects.
After the study, follow-up questionnaires provided deeper insight into the results which point to a significant difference in answers for self- and peer-led lessons and also demonstrate that the significance of the results varied based on whether student-taught lessons were led by pairs, groups, or individuals.

現在、日本の多くの教育者が、言語学習における学生主体のアプローチを求めている。しか、このような教授法への理解 と実践は一様ではなく、効果的な方法を支援する研究も少ない。本研究は、日本人EFL大学生を対象に、学生主体の学習への 態度を調査し、教師、学生自身、クラスメイトが授業の準備と指導に関与することで、学生の言語獲得に対する認識がゼう変化 するかを明らかにした。四クラスの学生が個人、ペア、グループで授業を行い、学生は、教師から与えられた記事を元に、授業 の構成を考え、実施し、定量形式のアンケートに回答した。調査後、フォローアップアンケートにより、定量的結果についてより 深い洞察が得られた。学生が個人で教える場合とペアになって教える場合では回答に大きな違いがあり、また、学生による授 業がペア、グループ、個人のいずれによって行われたかにより結果の有意性が異なることが示された。

he Japanese education system has been critiqued for being teacher-centered and

emphasizing standardized education (Takayama \& Lingard, 2019). In recent years, some educators have begun promoting student-centered classrooms, in particular in science, technology, engineering, and mathematics (STEM) courses to encourage creativity (Takahashi, 2006). Language classes would seem to be a forum wherein learnercentered pedagogies could yield rich results, however, as Kuwamura (2014) notes, the field of learner-centered pedagogy in Japan is still misunderstood and terms such as student-centered are frequently misapplied.

Learner agency is central to student-centered learning. Beginning in the 1930s, the term was used to distinguish it from dominant teacher-centered approaches (Jones, 2007). Student-centered means that the classroom and materials are personalized and flexible enough to incorporate learning needs, assessment, and cultural factors. The teacher is seen as a facilitator, with the goal of increasing learner agency and independence (Rust, Price, \& O'Donovan, 2003). Learner agency is thus a conscious effort undertaken by the learners themselves.

In language learning, student-centered classrooms foster greater goal awareness, increase fluency, enhance self-efficacy, increase motivation, and encourage metacognitive efforts (Braine, 2003; Hamilton, 2010; Sweet, Mack, \& Olivero-Agney, 2019; Taylor, 
1983; Xiao, 2014). They have also been beneficial in other educational fields besides language education, for example, the sciences (Kang \& Keinonen, 2018). In fact, while some disciplines have incorporated group work and creative problem solving into even primary education, it is only recently that scholars have begun to examine the efficacy of flipped, student-centered classrooms in the field of language study (Mehring, 2016). In addition, there is a paucity of studies on the efficacy of learner-centered pedagogies in Japan; many of them note cultural difficulties in adapting this style of pedagogy (Kuwamura, 2014). Thus, few studies have quantitatively and qualitatively assessed the efficacy of student-centered pedagogies in Japan. This research aims to overcome this gap through its examination of learner agency in a student-centered classroom based on the presentation of an article taught and assessed by peers.

\section{Research Questions}

This study examines Japanese EFL university students' attitudes towards studentcentered learning through the following research questions:

RQ1. After completing student-centered learning activities, will students' perceptions of their language gains change when the teacher solely prepares and teaches the materials?

RQ2. Do students' perceptions of their language gains change when they are involved in the preparation and instruction of course materials?

RQ3. Do students' perceptions of their language gains change when their peers prepare and teach course materials?

\section{Methodology}

\section{Participants}

A total of 109 students (46 female and 63 male) from three universities in western Japan consented to participate in this study. To answer our research questions and determine whether class size influences students' attitudes towards student-centered learning, four intact EFL classes where students could prepare and teach lessons either individually, in pairs, in groups of three to four, or in groups of five to six were selected. Before beginning the study, nine articles were added to a class Learning Management System (LMS) for participants to review and rank their interest in each article. Based on these rankings, students were grouped and assigned one of the articles. The class wherein students did the activity individually was a compulsory intermediate class, while the remaining three courses were elective classes, open to students regardless of level. The details of the four class groups are shown in Table 1 . They were taught by three of the researchers.

Table 1. Class Data

\begin{tabular}{|c|c|c|c|}
\hline Individual & Pairs & Groups of 3-4 & Groups of 5-6 \\
\hline $\begin{array}{l}9 \text { participants ( } 4 \\
\text { female, } 5 \text { male) }\end{array}$ & $\begin{array}{l}18 \text { participants ( } 8 \\
\text { female, } 10 \text { male) }\end{array}$ & $\begin{array}{l}32 \text { participants ( } 3 \\
\text { female, } 22 \text { male) }\end{array}$ & $\begin{array}{l}50 \text { participants ( } 31 \\
\text { female, } 19 \text { male) }\end{array}$ \\
\hline Intermediate level & Mixed levels & Mixed levels & Mixed levels \\
\hline 3rd-year students & $\begin{array}{l}\text { 2nd-4th-year } \\
\text { students }\end{array}$ & $\begin{array}{l}\text { 3rd- and 4th-year } \\
\text { students }\end{array}$ & $\begin{array}{l}\text { 3rd and 4th-year } \\
\text { students }\end{array}$ \\
\hline $\begin{array}{l}\text { Seminar class in } \\
\text { Faculty of Liberal } \\
\text { Arts }\end{array}$ & $\begin{array}{l}\text { Elective Life Topics } \\
\text { class in Faculty of } \\
\text { Literature }\end{array}$ & $\begin{array}{l}\text { Elective culture } \\
\text { class in Faculty of } \\
\text { Agriculture }\end{array}$ & $\begin{array}{l}\text { Elective culture } \\
\text { class in Faculty of } \\
\text { Agriculture }\end{array}$ \\
\hline
\end{tabular}

Prior to beginning the study, researchers confirmed that the students understood the project and freely agreed to participate, and institutional clearance was also obtained.

\section{Materials Design}

Instruments for Data Collection

At the onset of the study, participants were given a bilingual questionnaire consisting of six Likert-scale questions to gauge their attitudes towards their teacher's, peers', and their own role in preparing and teaching materials to improve language ability. The Japanese translation of this survey is shown in Appendix A. The respondents were asked to rate the following six statements on a 6-point interval scale ranging from 1 (strongly disagree) to 6 (strongly agree). The first two items on the questionnaire, given below, were asked to answer our first research question as given above:

1. My language ability improves more when the materials for the lesson are prepared exclusively by the teacher.

2. My language ability improves more when the lesson materials are taught exclusively by the teacher. 
The second two items were asked to investigate our second research question:

3. My language ability improves more when I am involved in preparing the materials for the lesson.

4. My language ability improves more when I am involved in teaching the lesson materials to my classmates.

The final two questions were used to answer our third research question:

5. My language ability improves more when the materials for the lesson are prepared by my classmates.

6. My language ability improves more when the lesson materials are taught by my classmates.

The participants were given the same questionnaire after the study to see if their attitudes changed after the interaction of student-centered learning. All of the items were translated into Japanese and then checked by a professional for accuracy. After the quantitative analysis of the pre- and post-study questionnaire data, a follow-up survey was administered to gain insight into participants' responses. Students were told that their answers to questions 3-6 had changed and were asked to explain changes in their perceptions towards the teacher's and students' role in preparing and teaching materials.

\section{Simplified Articles}

Twelve simplified articles were used in this study. The articles were prepared by the researchers to be of similar length (420-440 words) and lexical difficulty $(90-93 \%$ coverage of the first 2000 words on the New General Service List). They were simplified using the lexical text analysis software VocabProfile (Cobb, 2015). Each article shared identical formatting. Four of the articles were about food, four about pop culture, and four about communication and identity. Appendix B shows the sequencing, theme, and title of each article.

\section{Class Assignment}

Each week, students were required to read and complete a discussion worksheet for one of the 12 article-based lessons. The first three article-based lessons were taught by the teacher and were examples to show the students what was expected, whereas the final nine article-based lessons were prepared and taught by the students (Appendix B). Each student taught one of the articles either individually, in pairs, in groups of three to four, or in groups of five to six, depending on class size. The project was introduced in the second class before the first article was taught by the teacher. Before the second class, the remaining nine articles were uploaded to an LMS. For homework, students were asked to select four articles that they were interested in and rank them 1 to 4 . Based on these rankings, the teachers assigned students to an article the following week. Students were given a class period to prepare their presentation and activities. A description of the assignment is given in Appendix $C$, and Appendix D is an example of a student presentation. Finally, students were given a handout (Appendix E) of presentation language to use to ameliorate difficulties of varying levels of language proficiency.

\section{Data Analysis}

A series of paired-samples $t$ tests for each research question were conducted for each group to compare learners' attitudes pre- and post-study. After the quantitative analysis of the pre- and post-study questionnaire data was complete, a follow-up survey was administered to gain insight into participant responses.

\section{Results}

\section{Research Question 1}

The first research question concerned learners' attitudes towards the teacher preparing and teaching materials pre- and post-study. To answer this question, a series of pairedsamples $t$ tests were performed for each group. 
Tanaka, Sheridan, Tang, \& Kobayashi: Bridging Pedagogical Gaps with Learner Agency

Table 2. Learner Attitudes Towards the Teacher Exclusively Preparing Materials

\begin{tabular}{lccccccc}
\hline Group & Test & Mean & SD & $\begin{array}{c}\text { Difference of M } \\
\text { Post-Pre }\end{array}$ & $t$ & $D f$ & $p$ \\
\hline Individuals & Pre-study & 4.22 & 0.67 & 0.33 & 2 & 8 & $p=.081$ \\
& Post-study & 4.56 & 0.73 & & & & \\
Pairs & Pre-study & 4.31 & 0.70 & 0 & 0 & 15 & $p=1.00$ \\
& Post-study & 4.31 & 0.95 & & & & \\
Groups of & Pre-study & 4.72 & 0.96 & 0.25 & 1.16 & 31 & $p=.255$ \\
3-4 & Post-study & 4.97 & 0.82 & & & & \\
Groups of & Pre-study & 4.72 & 0.86 & 0.16 & 1.24 & 49 & $p=.220$ \\
$5-6$ & Post-study & 4.88 & 0.72 & & & & \\
\hline
\end{tabular}

The first series of paired-samples $t$ tests compared the mean of learners' attitudes towards the teacher exclusively preparing materials to improve their language gains pre- and post-study. As shown in Table 2, the results indicated that the mean of learners' attitudes were higher post-study in three of the four groups; however, these differences were not statistically significant for Individuals $(t(8)=2, p=.081)$, Groups of 3-4 $(t(31)$ $=1.16, p=.255)$, and Groups of 5-6 $(t(49)=1.24, p=.22)$. The Pairs group's attitudes remained unchanged $(t(0)=15, p=1.00)$
Table 3. Learner Attitudes Towards the Teacher Exclusively Teaching Materials

\begin{tabular}{lccccccc}
\hline Group & Test & Mean & SD & $\begin{array}{c}\text { Difference of M } \\
\text { Post-Pre }\end{array}$ & $t$ & $d f$ & $p$ \\
\hline Individuals & Pre-study & 4.33 & 0.50 & 0.22 & 1.00 & 8 & $p=.347$ \\
& Post-study & 4.56 & 0.88 & & & & \\
Pairs & Pre-study & 4.13 & 0.89 & 0.31 & 0.96 & 15 & $p=.352$ \\
& Post-study & 4.44 & 1.09 & & & & \\
Groups of & Pre-study & 4.81 & 0.86 & 0.19 & 1.36 & 31 & $p=.184$ \\
3-4 & Post-study & 5.00 & 0.76 & & & & \\
Groups of & Pre-study & 4.80 & 0.86 & 0.22 & 1.91 & 49 & $p=.062$ \\
$5-6$ & Post-study & 5.02 & 0.77 & & & & \\
\hline
\end{tabular}

The second series of paired-samples $t$ tests were conducted to evaluate learners' attitudes towards the teacher exclusively teaching materials to improve their language gains pre- and post- study. As displayed in Table 3, the results showed that the mean of learners' attitudes slightly increased post study in all of the groups; however, there was not a significant difference in the mean scores for any of the groups (Individuals $(t(8)=1$, $p=.347)$, Pairs $(t(15)=0.96, p=.352)$, Groups of $3-4(t(31)=1.36, p=.352)$ and Groups of $5-6(t(49)=1.91, p=.062))$.

\section{Research Question 2}

The second research question examined whether learners' perceptions of their language gains changed towards their involvement in the preparation and instruction of course materials after they participated in the experimental treatment. A series of paired-

samples $t$ tests were performed for each group to compare learners' attitudes pre- and post-study. 
Tanaka, Sheridan, Tang, \& Kobayashi: Bridging Pedagogical Gaps with Learner Agency

Table 4. Learner Attitudes Towards Their Own Involvement in Preparing Materials

\begin{tabular}{lccccccc}
\hline Group & Test & Mean & SD & $\begin{array}{c}\text { Difference of M } \\
\text { Post-Pre }\end{array}$ & $t$ & $d f$ & $p$ \\
\hline Individuals & Pre-study & 4.56 & 1.13 & 0.67 & 1.41 & 8 & $p=.195$ \\
& Post-study & 5.22 & 0.67 & & & & \\
Pairs & Pre-study & 4.38 & 1.09 & 0.31 & 0.84 & 15 & $p=.416$ \\
& Post-study & 4.69 & 0.93 & & & & \\
Groups of & Pre-study & 4.47 & 1.16 & 0.72 & 3.19 & 31 & $p=.003$ \\
3-4 & Post-study & 5.19 & 0.86 & & & & \\
Groups of & Pre-study & 4.30 & 1.02 & 1.00 & 6.09 & 49 & $p<.001$ \\
$5-6$ & Post-study & 5.30 & 0.76 & & & & \\
\hline
\end{tabular}

As shown in Table 4, the results indicated that learners' attitudes towards their language gains when they are involved in the preparation of course materials increased post-study in all of the groups and there were significant differences in the mean scores for Groups of 3-4 $(t(31)=3.19, p=.003, d=.56)$ and Groups of 5-6 $(t(49)=6.09, p<.001$ $d=.83)$. However, there was not a significant difference in the Individuals $(t(8)=1.41, p$ $=.195)$ or Pairs $(t(15)=0.84, p=.416)$ groups. The effect size, as assessed by Cohen's $d$, was medium $(d=.56)$ for Groups of 3-4 and large $(d=.83)$ for the Groups of 5-6. Cohen (1992) suggested that $d=0.2$ be considered a small effect size, 0.5 a medium one, and 0.8 a large one.
Table 5. Learner Attitudes Towards Their Own Involvement in Teaching Materials

\begin{tabular}{lccccccc}
\hline Group & Test & Mean & SD & $\begin{array}{c}\text { Difference of M } \\
\text { Post-Pre }\end{array}$ & $t$ & $d f$ & $p$ \\
\hline Individuals & Pre-study & 4.44 & 1.24 & 0.44 & 0.74 & 8 & $p=.482$ \\
& Post-study & 4.89 & 1.05 & & & & \\
Pairs & Pre-study & 4.25 & 1.18 & 0.69 & 2.42 & 15 & $p=.029$ \\
& Post-study & 4.94 & 0.93 & & & & \\
Groups of & Pre-study & 4.44 & 1.16 & 0.75 & 3.56 & 31 & $p=.001$ \\
3-4 & Post-study & 5.19 & 0.86 & & & & \\
Groups of & Pre-study & 4.44 & 1.05 & 0.80 & 5.03 & 49 & $p<.001$ \\
$5-6$ & Post-study & 5.24 & 0.82 & & & & \\
\hline
\end{tabular}

The results, as displayed in Table 5, revealed that learners' perceptions of their language gains when they are involved in the instruction of course materials was also greater post-study in all of the groups. These differences in mean scores were significant for Pairs $(t(15)=2.42, p=.029, d=.60)$, Groups of $3-4(t(31)=3.56, p=.001, d=.61)$, and Groups of 5-6 $(t(49)=5.03, p=<.001, d=.71)$ and suggested a medium-sized effect for all three of these groups, $d=.60, d=.61$ and $d=.71$ respectively. The difference in mean scores was not significant for Individuals $(t(8)=0.74, p=.482)$.

\section{Research Question 3}

To answer the third research question of whether learners' perceptions of their language gains change when their peers prepare and teach course materials after the interaction, a series of paired-samples $t$ tests were performed for each group. 
Tanaka, Sheridan, Tang, \& Kobayashi: Bridging Pedagogical Gaps with Learner Agency

Table 6. Learner Attitudes Towards Their Classmates' Involvement in Preparing Materials

\begin{tabular}{lccccccc}
\hline Group & Test & Mean & SD & $\begin{array}{c}\text { Difference of M } \\
\text { Post-Pre }\end{array}$ & $t$ & $d f$ & $p$ \\
\hline Individual & Pre-study & 3.78 & 0.97 & 0.22 & 0.56 & 8 & $p=.272$ \\
& Post-study & 4.00 & 0.87 & & & & \\
Pairs & Pre-study & 3.94 & 1.18 & 0.31 & 0.79 & 15 & $p=.441$ \\
& Post-study & 4.25 & 1.13 & & & & \\
Groups of & Pre-study & 3.75 & 1.08 & 0.50 & 2.43 & 31 & $p=.021$ \\
3-4 & Post-study & 4.25 & 1.11 & & & & \\
Groups of & Pre-study & 3.86 & 1.03 & 0.70 & 4.07 & 49 & $p<.001$ \\
$5-6$ & Post-study & 4.56 & 0.91 & & & & \\
\hline
\end{tabular}

As shown in Table 6, the results showed that learners' perceptions of their language gains when their classmates are involved in the preparation of course materials increased post-study in all of the groups. There were significant differences in the mean scores for Groups of 3-4 $(t(31)=2.43, p=.021, \mathrm{~d}=.43)$ and Groups of 5-6 $(t(49)=4.07, p<.001$, $d=0.58)$, and the effect size, as assessed by Cohen's $d$, was small to medium $(d=.43)$ for Groups of 3-4, and medium $(d=0.58)$ for Groups of 5-6. However, there were no significant differences in mean scores for the Individuals $(\mathrm{t}(8)=0.56, p=.272)$ or Pairs ( $\mathrm{t}$ $(15)=0.79, p=.272$ ) groups.
Table 7. Learner Attitudes Towards Their Classmates' Involvement in Teaching Materials

\begin{tabular}{lccccccc}
\hline Group & Test & Mean & SD & $\begin{array}{c}\text { Difference of M } \\
\text { Post-Pre }\end{array}$ & $t$ & $d f$ & $p$ \\
\hline Individuals & Pre-study & 3.67 & 1.00 & 0.44 & 1.18 & 8 & $p=.272$ \\
& Post-study & 4.11 & 1.17 & & & & \\
Pairs & Pre-study & 3.88 & 1.20 & -0.06 & -0.16 & 15 & $p=.872$ \\
& Post-study & 3.94 & 1.06 & & & & \\
Groups of & Pre-study & 4.06 & 0.95 & 0.47 & 2.01 & 31 & $p=.053$ \\
3-4 & Post-study & 4.53 & 1.16 & & & & \\
Groups of & Pre-study & 4.12 & 1.04 & 0.46 & 2.93 & 49 & $p=.005$ \\
5-6 & Post-study & 4.58 & 0.95 & & & & \\
\hline
\end{tabular}

The results, as displayed in Table 7, indicated that learners' attitudes of their language gains when their peers taught course materials increased post-study in 3 of the 4 groups and there was a significant difference in the scores for the group of 5-6 $(t(49)=2.93, p=$ $.005, d=.41)$ with a small to medium $(d=.41)$ effect size as assessed by Cohen's $d$. There were no significant differences in mean scores for the Individuals $(\mathrm{t}(8)=1.18, p=.272)$ or Groups of 3-4 $(t(31)=2.01, p=.053)$ groups and the Pairs group had a greater perception of their language gains when their peers taught course materials pre-study. However, this result was insignificant $(\mathrm{t}(15)=-0.16, p=.872)$.

\section{Discussion}

As noted in our statistical analysis, the study yielded significant results for our second and third research questions for classes where students worked in groups, indicating that their view of peer participation and student-centered classrooms (particularly their own involvement) shifted, but their evaluation of teacher-led classes did not. Changes in answers to questions towards their classmates' involvement in teaching and preparing materials reflected a change in student attitude towards their participation in lessons that were prepared and taught by peers. In contrast, the lack of significant shift in responses to the first two questions signaled that students' attitudes towards teachers' roles in preparing or teaching materials was unchanged. 
Upon seeing the shift in the questionnaire data, we administered a follow-up survey in Japanese. Students responded in English and Japanese. Where the students wrote in English, the researchers lightly edited their comments for clarity. All Japanese responses were translated into English by the researchers and checked by a professional translator. The question we asked in Japanese was:

In the last semester, there was a large shift in the answers to questions 3-6. In comparison to the first responses, on the final survey the average numbers were higher. To help us understand your feelings underlying the changes, please write your reasons in response to the questions below. As much as possible, please use English.

Questionnaire Results: Pairs and Groups Ranked the Activity Higher First, students who worked in pairs or groups recorded higher scores on the postclass questionnaire than they recorded on the pre-study questionnaire. This is likely because students who worked in groups met to work on their lessons and practice. This is reflected in student feedback: students who worked in pairs or groups emphasized the amount of time spent working together impacted their experience. One student remarked: "We had to look so much up," and another stated, "We all had to understand." Some students highlighted the importance of practice, indicating that students working in pairs and groups spent more time going over the material together. The process of materials creation and class planning became collaborative and an important source of study. One student wrote their thoughts in English and noted, "I think the process [of] making the material makes me higher level." Thus, collaboration in developing lessons was more important for students than the end result of peer teaching. In addition, students were motivated by their peers' ideas. One student stated, "I will be encouraged when I see my friends doing their best. There is a lot to learn from the materials and presentations made by students."

\section{Questionnaire Results: Criticism}

The groups were also more critical of themselves, or critical of groups, rather than individuals. Students often blamed themselves, rather than their peers, when lessons did not go well. One student remarked, "I feel my listening ability is not so high so it may not be able to be heard even if it is explained," and a second said, "I think this question [questions 5 \& 6] depends on [the] students. For example, [if] one person study hard, [then] we can learn some thing, but [if] another don't study, we can't learn something."
In contrast to this, students in the classes taught by individuals noted that they specifically liked some lessons but did not like others. In some cases, the students being taught directly stated this was an issue with the lesson plan. One student remarked that when their classmate taught, "the lesson was difficult to follow. I didn't understand the point." More often, students focused on the content of their peers' lessons and were more critical of students they disagreed with. For example, in their final questionnaire, some students in the individually taught group singled out a student who taught a lesson on the use of swastikas in Asian fashion because the student teacher included a discussion of Nazi contributions to German society. The students noted that their peer taught "the wrong opinion," and the teacher should "be careful."

\section{Questionnaire Results: English Ability and Class Levels}

Another important difference between group-led lessons and individually planned lessons was that group-led lessons ensured more uniformity in English levels. Feedback for lessons taught in groups included comments such as "I think [that my] classmates' material use is easy for understand because their English skill [is] probably [the] same. So, [it's] easy to understand." One student remarked on the post-class questionnaire that "the level was all similar" for the classes. A second student noted that "I think it's easy to do [these classes] with teaching materials written in easy-to-understand English." Classes taught by individuals, however, had less uniformity in levels and this was cited as problematic by several students. One student remarked, "My classmates have a high-level ability so the materials is difficult for me," while a second noted, "some of the lessons are so simple. It's not interesting."

Students in all groups pointed to problems with student-created materials and wanted more teacher supervision. Group-taught class feedback included, "I think classmates teaching is not all right, and classmates lesson is not correct and [styles are] different," and a second student said, "I think that materials the teacher make are better." Similarly, students who taught in pairs gave feedback that included, "The teaching materials created by classmates are not perfect. So I need my own understanding." Finally, students who taught lessons individually wrote that in some cases, "Student homework needed more research," or it was "too easy." These results indicate that some teacher supplementation of the materials, or greater supervision of the students, would be desirable. 


\section{Conclusion}

Many educators in Japan are actively utilizing student-centered pedagogies, yet they lack a clear understanding of tools and benefits to such approaches. This study bridged practice and results through research into student attitudes towards student-centered learning in Japanese tertiary education. Through having students as individuals, in pairs, or in groups design lesson plans and homework, and tracking their responses to peer-led lessons both pre- and post-study, researchers were able to quantitatively and qualitatively gauge the impact of student-centered pedagogical practices. The researchers demonstrated overall positive responses to student-led lessons and identified areas for further research or experimentation.

Despite uneven English levels and the fact that perceptions of the teacher's role did not change, overall, students had positive responses to student-centered exercises. Feedback was positive and included comments like, "my language skills improve more" with this pedagogical method. As students noted, the process of taking articles, then researching the topic to make materials allowed them "more opportunities to touch English." Finally, students frequently remarked that they appreciated being exposed to opinions and ideas other than their own or the teacher's. One student remarked that they looked forward to every class because "I am interested in what my classmates made."

This examination of the impact of learner-agency-focused classrooms opens up avenues for study into the impact of student-centered lessons on student motivation and engagement. Broadly, our study revealed positive qualitative and quantitative results. The techniques that yielded these positive results are flexible, thus this pedagogical method can be easily adapted to many classrooms.

\section{Bio Data}

Kathryn M. Tanaka $(\mathrm{PhD})$ is an associate professor of cultural and historical studies at Otemae University in Nishinomiya, Japan. Her research interests include culture in education, CLIL, human rights, and literature in language education.

Robert Sheridan (MSEd in TESOL) is an associate professor in the Faculty of Agriculture at Kindai University in Nara, Japan. He serves as the program chair of Osaka JALT. His research interests include vocabulary acquisition, CLIL, extensive reading, motivation, and culture in education.

Daniel Tang is a lecturer at Otemae University. His interests are Peace Studies, English pedagogy, International Relations in East Asia and CALL.
Jeanette Kobayashi has been teaching English language at universities in Japan for more than 10 years, holds a MSEd from Niagara University, NY and is currently teaching at Konan University. Her research interests include constructivist teaching methodology, active learning and student-centered learning.

\section{References}

Braine, G. (2003). From a teacher-centered to a student-centered approach: A study of peer feedback in Hong Kong writing classes. Journal of Asian Pacific Communication, 13(2), 269-288. https://doi.org/10.1075/japc.13.2.05bra

Cobb, T. (2015). Complete web VP [computer program]. Retrieved from http://www.lextutor.ca/vp/comp/

Cohen, J. (1992). A power primer. Psychological Bulletin, 112(1), 155-159.

https://doi.org/10.1037/0033-2909.112.1.155

Hamilton, R. (2010). YouTube for two: Online video resources in a student-centered, task-based ESL/EFL environment. Contemporary Issues in Education Research, 3(8), 27-32. https://doi.org/10.19030/cier.v3i8.224

Jones, L. (2007). The student-centered classroom. New York, NY: Cambridge University Press.

Kang, J. \& Keinonen, T. (2018). The effect of student-centered approaches on students' interest and achievement in science: Relevant topic-based, open and guided inquiry-based, and discussionbased approaches. Research in Science Education, 48(4), 865-885. https://doi.org/10.1007/s11165016-9590-2

Kuwamura, T. (2014). Acceptance and transformation of English educational theory in Japan: On student-centered education. International Education Studies, 7(12), 47-52. https://doi.org/10.5539/ies.v7n12p47

Mehring, J. (2016). Present research on the flipped classroom and potential tools for the EFL classroom. Computers in the Schools, 33(1), 1-10. https://doi.org/10.1080/07380569.2016.1139912

Rust, C., Price, M., \& O'Donovan, B. (2003). Improving students' learning by developing their understanding of assessment criteria and processes. Assessment and Evaluation in Higher Education, 28(2), 147-164. Retrieved from http://area.fc.ul.pt/artigos\%20publicados\%20 internacionais/lmproving\%20students\%20learning.pdf

Sweet, G., Mack, S., \& Olivero-Agney, A. (2019). Where am I? Where am I going, and how do I get there? Increasing learner agency through large-scale, self-assessment in language learning. In P. Winke \& S. Gass (Eds.), Foreign language proficiency in higher education (pp. 175-195). New York, NY: Springer.

Takahashi, A. (2006). Characteristics of Japanese mathematics lessons. Tsukuba Journal of Educational Study in Mathematics, 25(1), 37-44. 
Takayama, K. \& Lingard, B. (2019). Datafication of schooling in Japan: An epistemic critique through the 'problem of Japanese education.' Journal of Education Policy. 34(4), 449-469. https://doi.org/10.1080/02680939.2018.1518542

Taylor, B. P. (1983). Teaching ESL: Incorporating a communicative, student-centered component. TESOL Quarterly, 17(1), 69-88. https://doi.org/10.2307/3586425

Xiao, J. (2014). Learner agency in language learning: The story of a distance learner of EFL in China. Distance Education, 35(1), 4-17. https://doi.org/10.1080/01587919.2014.891429

\section{Appendix A}

Bilingual Questionnaire

\section{1. 教師が作った教材を使うと、自分の語学力がより上達する。}

My language ability improves more when the materials for the lesson are prepared exclusively by the teacher.

2. 教師が教材について説明すると、自分の語学力がより上達する。

My language ability improves more when the lesson materials are taught exclusively by the teacher.

\section{3. 教材づくりに自分も関わると、自分の語学力がより上達する。}

My language ability improves more when I am involved in preparing the materials for the lesson.

4. 自分がクラスメートに教材について説明すると、自分の語学力がより上達する。

My language ability improves more when I am involved in teaching the lesson materials to my classmates.

\section{5. クラスメートが作った教材を使うと、自分の語学力がより上達する。}

My language ability improves more when the materials for the lesson are prepared by my classmates.

6. クラスメートが教材について説明すると、自分の語学力がより上達する。

My language ability improves more when the lesson materials are taught by my classmates.

\section{Appendix B}

\section{Course Outline}

\begin{tabular}{|c|c|c|c|}
\hline Class & & Themes & Titles of the articles \\
\hline 1 & & & Course Outline and Ice-breaker activities \\
\hline 2 & \multirow{3}{*}{$\begin{array}{l}\text { Articles } \\
\text { taught by } \\
\text { teacher }\end{array}$} & $\begin{array}{l}\text { Communication } \\
\text { and Identity }\end{array}$ & The Eyes of Manga Characters \\
\hline 3 & & Food & Food for the Gods: Japanese Food Ritual \\
\hline 4 & & Pop Culture & Animation in Japan \\
\hline 5 & & & Prepare your presentation and activities \\
\hline 6 & \multirow{10}{*}{$\begin{array}{l}\text { Articles } \\
\text { taught by } \\
\text { students }\end{array}$} & $\begin{array}{l}\text { Communication } \\
\text { and Identity }\end{array}$ & $\begin{array}{l}\text { Noodle company apologizes for 'white- } \\
\text { washing' }\end{array}$ \\
\hline 7 & & Food & Pop Culture in Food \\
\hline 8 & & Pop Culture & Human Rights and Japanese Pop Culture \\
\hline 9 & & $\begin{array}{l}\text { Communication } \\
\text { and Identity }\end{array}$ & $\begin{array}{l}\text { Thai girl band BNK48 sorry for Nazi T-shirt } \\
\text { controversy }\end{array}$ \\
\hline 10 & & Food & Eating Alone in Japan \\
\hline 11 & & Pop Culture & Translations of Music \\
\hline 12 & & $\begin{array}{l}\text { Communication } \\
\text { and Identity }\end{array}$ & $\begin{array}{l}\text { Status in Language - The Language Debate } \\
\text { Inside Japan's Convenience Stores }\end{array}$ \\
\hline 13 & & Food & Being Polite at a Coffee Shop \\
\hline 14 & & Pop Culture & Smartphone Addiction \\
\hline 15 & & & Final Test \\
\hline
\end{tabular}




\section{Appendix C}

Instructions for the Student-Centered Class Assignment

\section{Your PowerPoint presentation must include:}

- An Introduction

- An Overview

- A description of the article (what are the main 4 or 5 points of the article)

- Your opinion(s) (what do you think about the article)

- Three discussion questions for the class to discuss (think about questions about the article and/or themes in the article)

- Two post-reading activities (plan activities for your classmates based on the article and/or themes)

- At the end of your lesson your classmates can ask you questions

*Use the "Presenting an article" handout to help you

*Needs to be 45-60 minutes

*You must send to your teacher at least two days before your presentation

\section{Appendix D}

Example of a Student Presentation

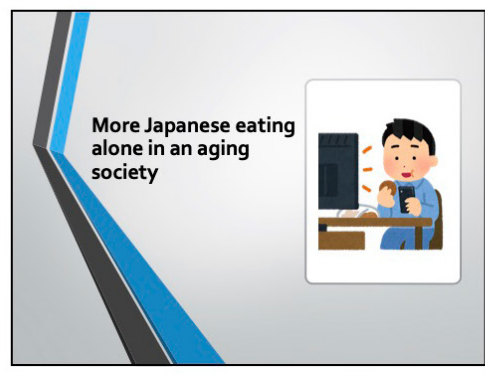

Summary: What is "eating alone"?
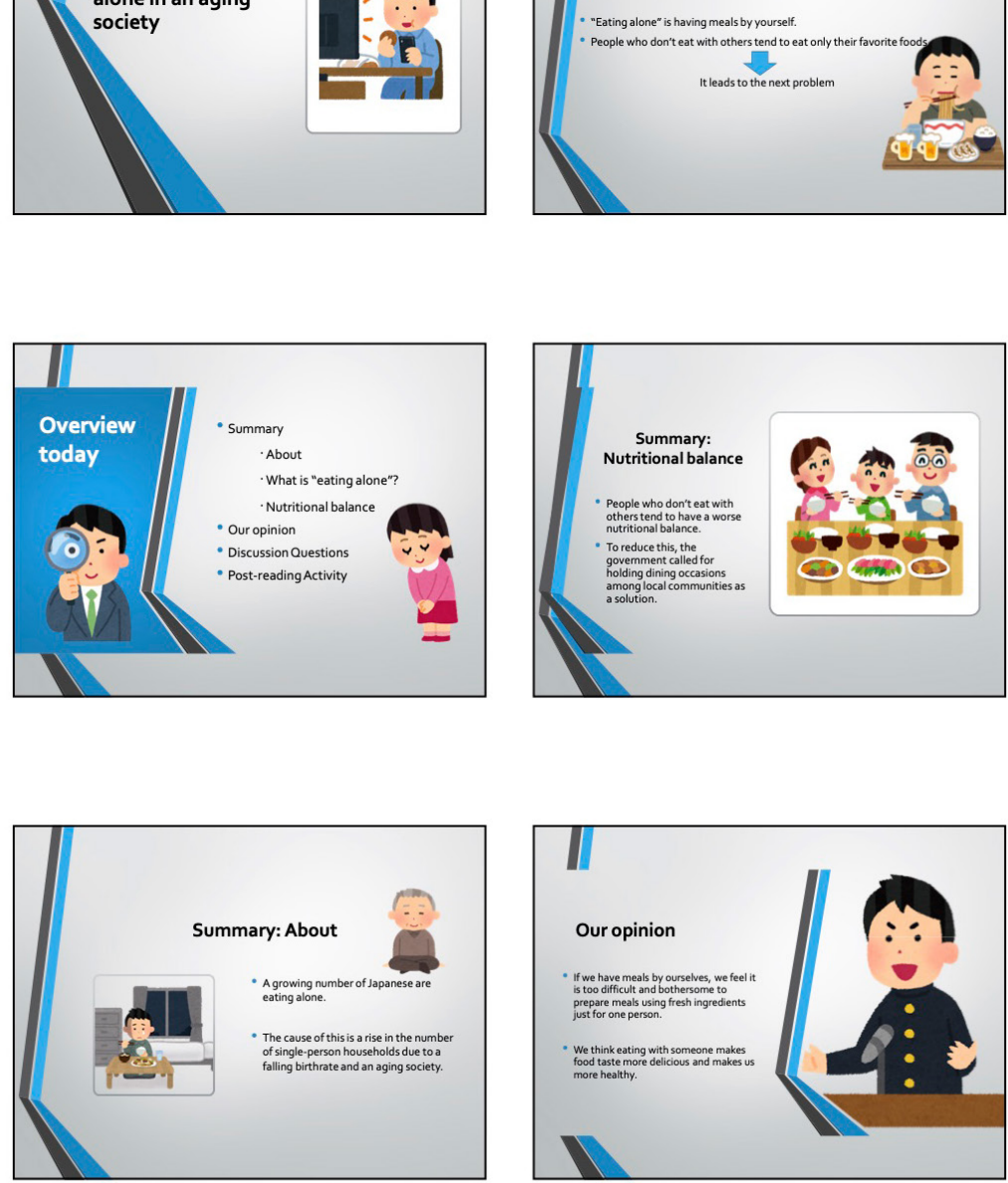

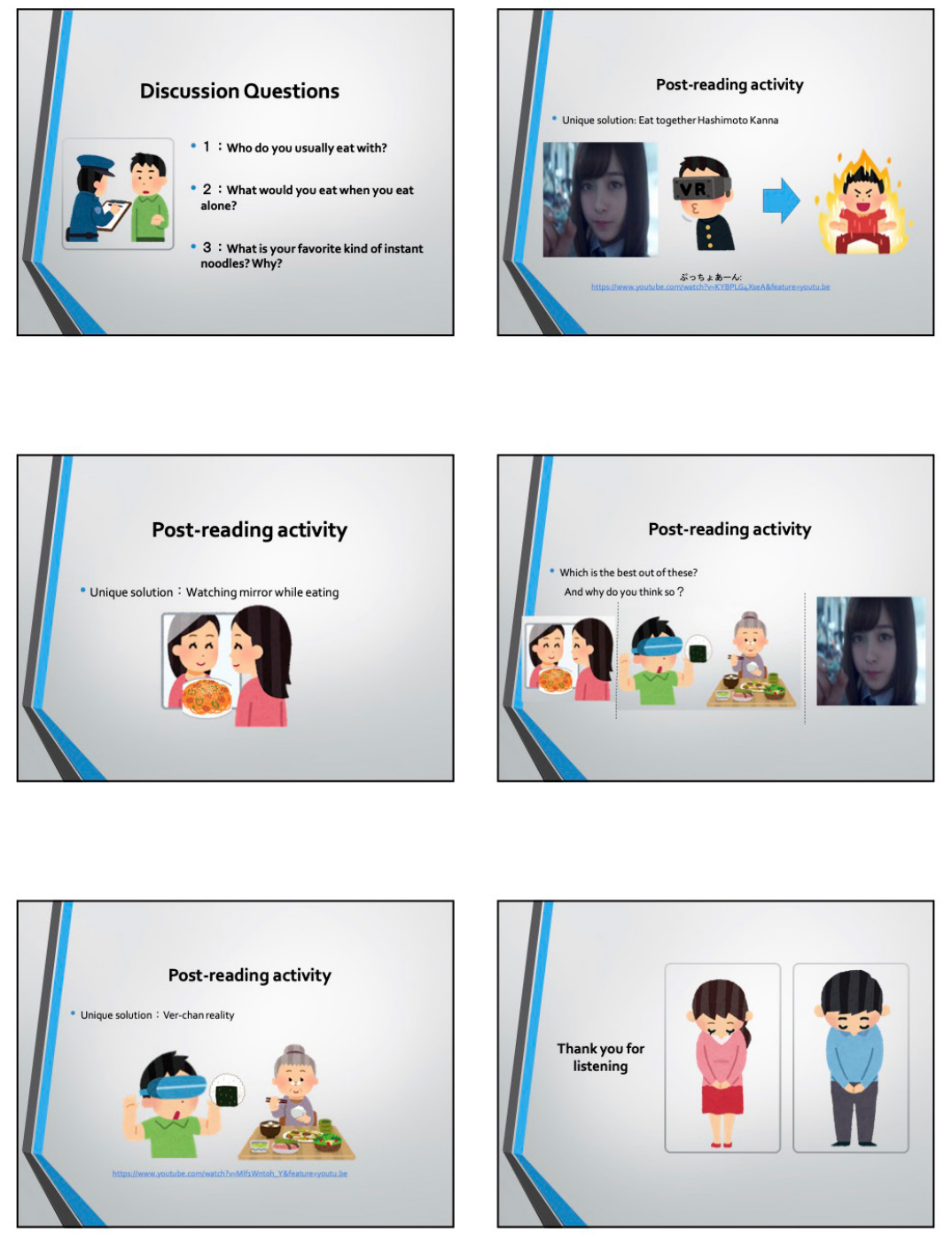

\section{Appendix E}

\section{Presentation Language to Use When Presenting an Article}

\section{Presenting an Article}

\section{Introduction}

Good morning/afternoon. My name is

would like to report on an article about

In our presentation today, we

\section{Overview}

Before we get started, l'd like to give an overview of our presentation and introduce the members of our group.

First, _____ will be talking about the summary of the article.

Next, _________ will be giving our group's opinions about the article.

After that, ______ will be sharing the discussion questions we came up with and leading a class discussion.

Finally, _____________ will be leading a post-reading class activity.

\section{Describing the Article}

The title of the article is

It is a story about

It takes place in

We have summarized the article into four main parts.

1. First...

2. Second...

3. Third...

4. Finally...

\section{Offering your Opinion}

We (strongly) agree/disagree with this article because

article interesting because /We found this 


\section{Discussion Questions}

Our group came up with three discussion questions about the article.

1. First...

2. Second...

3. Finally...

We would like to give you 10 minutes to discuss these questions with a partner or in a small group and then we will choose some people to share their answers with the rest of the class.

\section{Post-reading Activity}

After reading the article, we came up with the following post-reading activity...

\section{Ending}

Thank you for listening to our presentation today. And now we'll be happy to answer

any questions you may have. 